\title{
Growth of young Brazilian mahogany (Swietenia macrophylla King) plants under different doses of calcium
}

\author{
Mário Lopes da Silva Júnior ${ }^{1}$, Sandra Andréa Santos da Silva ${ }^{2}$, Cassio Rafael Costa dos Santos* ${ }^{1}$, Vânia \\ Silva de Melo ${ }^{1}$, Mábia Maria Duarte Alcantra ${ }^{1}$, Rômulo José Alencar Sobrinho ${ }^{1}$, Augusto José Silva \\ Pedroso $^{3}$, Orivan Maria Marques ${ }^{4}$, Ismael de Jesus Matos Viégas ${ }^{1}$
}

\author{
${ }^{1}$ Universidade Federal Rural da Amazônia, Departamento de Ciências do Solo, Avenida Tancredo Neves, 2501, \\ Belém, PA, Brazil \\ 2Universidade Federal do Pará, Campus de Altamira, Rua José Porfino, 263 Altamira, PA, Brazil \\ ${ }^{3}$ Institudo de Educação, Ciência e Tecnologia do Pará, Campus Castanhal, BR-316 km 61, Castanhal, PA, Brazil \\ ${ }^{4}$ Embrapa Amazônia Oriental, Rua Dr. Enéas Pinheiro, Belém, PA, Brazil
}

\begin{abstract}
Knowledge of the nutritional status of vegetal species can anticipate the time at which seedlings are formed, which increases survival rate in the field after planting. The objective of this study was to evaluate the growth and nutrient content of mahogany seedlings according to increasing doses of $\mathrm{Ca}$ in the nutrient solution at a pressure ranging from 0.5 to $1.5 \mathrm{~atm}$ and a $\mathrm{pH}$ of 6 . Seedlings of mahogany plants at 45 days of age and with four well-defined leaves were selected for the experiment. The experimental design was completely randomized, with five treatments $\left(0,80,160,240\right.$ and $320 \mathrm{mg} \mathrm{L}^{-1}$ of $\left.\mathrm{Ca}\right)$ and five replications. At 71 days after treatment application, some variables were assessed: plant height, stalk diameter, root length, shoot dry matter (SHDM), root dry matter (RDM), SHDM/RDM ratio and Ca content in shoots and roots. The dose of maximum economic efficiency was $119 \mathrm{mg} \mathrm{L}^{-1}$, which corresponded to production of $27.79 \mathrm{~g}$ of total dry matter (TDM). The critical level of Ca for SHDM was 17.10 $\mathrm{g} \mathrm{kg}^{-1}$. For the dose of $320 \mathrm{mg} \mathrm{L}^{-1}$ of $\mathrm{Ca}$, a reduction in stalk diameter, root length, SHDM and RDM was observed when compared to the $240 \mathrm{mg} \mathrm{L}^{-1}$ dose. The greatest relative increment in mahogany plant growth was observed at the dose of $240 \mathrm{mg} \mathrm{L}^{-1}$ of Ca.
\end{abstract}

Key-words: Cationic Macronutrient; Forest Species; Mineral Nutrition; Seedling Production; Vegetative Growth.

Abbreviations: CaR_Calcium content in the roots; CaSH_Calcium content in the shoots; $\mathrm{CL}$ Critical level of Ca in shoot dry matter production; DMEE_Dose of maximum economic efficiency; DMPE_Dose of maximum physical efficiency; LDM_Leaf dry matter; RDM_Root dry matter; RPI_Relative percentage increment; STDM_Stalk dry matter; SHDM/RDM_Ratio between shoot and root dry matter; SHDM_Shoot dry matter; TO_Treatment with $0 \mathrm{mg} \mathrm{L}^{-1}$ of calcium; T160_Treatment with $160 \mathrm{mg} \mathrm{L}^{-1}$ of calcium; T240_Treatment with $240 \mathrm{mg} \mathrm{L}^{-1}$ of calcium; T320_Treatment with $320 \mathrm{mg} \mathrm{L}^{-1}$ of calcium; T80_Treatment with $80 \mathrm{mg} \mathrm{L}^{-1}$ of calcium; TDM_Total dry matter.

Introduction

Mahogany (Swietenia macrophylla King) is considered the main neotropical timber species due to its high value in the international market (Souza et al. 2010; Free et al., 2014). From decades of intense exploration and illegal extraction, this species has undergone a serious risk of extinction because the renewal of natural stocks did not follow the great national and international demand (Souza et al., 2008). Additionally, predatory extraction caused the deforestation of vast areas, especially in the Amazonian watershed (Rocha et al., 2016).

Planting or adoption of agroforestry systems using mahogany plants is a socioeconomic and ecological alternative in the restoration of degraded ecosystems (Viégas et al., 2012). However, the success of cultivation of mahogany and other species depends on the quality of the seedlings whose nutritional requirement has a decisive influence. The lack of information about nutritional requirements in young Brazilian mahogany plants has been reported as one of the limiting factors in forestation and reforestation projects. In this context, studies on the nutritional demand of mahogany at the seedling stage are fundamental for the establishment of a suitable fertilization programme over the cycle of the species, especially demand for Ca since this nutrient is not supposed to be used for fertilization in the process of forestry seedling production (Souza et al., 2010; Fernandes et al., 2013).

Moreover, adequate nutrition of mahogany with $\mathrm{Ca}$ provides a decrease in attacks by Hypsipyla grandella, the main pest of this crop, which destroys the terminal sprout of seedlings and adult plants due to formation of galleries by drill larvae (Silva et al., 2009).

It is important to emphasize that $\mathrm{Ca}$ is poorly studied in the nutrition of forestry species due to the use of liming, which complies with nutrient demand by plants. Studies highlight 
nutritional deficiency of $\mathrm{Ca}$ as the cause of reduction in the growth of plants, deformation of leaves and chlorosis, which may progress towards necrosis in the border of the leaf's blade, and petiole collapse in young leaves (Wallau et al., 2008; Viégas et al., 2012). Such troubles in the plant are due to the importance of $\mathrm{Ca}$ as a structural component of the cell wall and in processes such as cell division and differentiation, cytoplasmic movement and an increase in the cell volume (Malavolta, 2006).

The objective of this study was to evaluate the influence of Ca dose on growth and nutrient content, and to identify the dose of maximum efficiency in young plants of mahogany grown in nutrient solution.

\section{Results}

\section{Statistical and regression analysis of growth variables}

Based on adjustment of equations, it was observed that no variables significantly fitted a linear regression. For plant height, treatments were equal according to Tukey's test $(p<$ 0.05). However, stalk diameter, root length, shoot dry matter (SHDM) and root dry matter (RDM) showed T240 as the best treatment, in agreement with Tukey's test. According to the results of quadratic regression, the doses of Ca influenced $(p<0.05)$ variables of seedling growth, with the exception of plant height and SHDM/RDM (Table 1). For the variables that were significantly influenced by $\mathrm{Ca}$, the increase occurred until T240.

The SHDM/RDM of all doses did not change significantly in comparison to T0, evidencing that treatments did not restrict shoot and root development. RDM and SHDM adjusted themselves successfully to quadratic regression. It was observed that these variables were augmented until T240, with a decrease for T320 (Table 1). These results can be interpreted by considering the antagonism between $\mathrm{Ca}$ and other cations which provide a reduction of $\mathrm{K}$ and $\mathrm{Mg}$ absorption by plant roots, as observed by Rocha et al. (2008) in young hybrids of Eucalyptus grandis and E. urophylla and by Silva et al. (2008) in seedlings of Ceiba pentandra (L.) Gaertn.

The reduction in total dry matter (TDM), which was calculated by the difference between the smallest and the greatest results found for treatments T0, T80, T160 and T240, was 49\% (Table 1). This highlights the importance of Ca for vegetal metabolism, especially for the formation of cell walls and aggregation of structures (Malavolta, 2006).

\section{Analysis of relative percentage increment (RPI), dose of maximum physical efficiency (DMPE) and dose of maximum economic efficiency (DMEE)}

In general, RPI in leaves, stalk and roots was higher for doses of Ca between 160 and $240 \mathrm{mg} \mathrm{L}^{-1}$ (Fig. 1). The dry matter increment for different parts of the plant at these doses was higher than for the other doses of Ca applied. The results for leaf dry matter (LDM) and TDM were successfully adjusted to the quadratic model. DMPE was obtained with a dose of $221 \mathrm{mg} \mathrm{L}^{-1}$ and DMEE with a dose of $119 \mathrm{mg} \mathrm{L}^{-1}$, which corresponded to TDM production of $27.79 \mathrm{~g}$ (Fig. 2).

\section{Analysis of calcium content in the shoots (CaSH) and calcium content in the roots (CaR)}

The responses in $\mathrm{Ca}$ content ( $\mathrm{CaSH}$ and $\mathrm{CaR}$ ) presented better adjustment to quadratic and linear models, respectively. The estimated dose to reach the critical level (CL) of CaSH corresponded to the application of $119 \mathrm{mg} \mathrm{L}^{-1}$ estimated in $17.10 \mathrm{~g} \mathrm{~kg}^{-1}$ of SHDM (Fig. 3).

The intersection point between adjusted equations for $\mathrm{CaSH}$ and $\mathrm{CaR}$ was found at a dose of $192 \mathrm{mg} \mathrm{Ca} \mathrm{L}^{-1}$, which corresponds to about $19 \mathrm{~g} \mathrm{Ca} \mathrm{kg}^{-1}$ of dry matter. At TO, it was verified that $\mathrm{Ca}$ content in the shoots was superior to that in the roots, which could be related to the priority of shoot development in young mahogany plants when $\mathrm{Ca}$ absorption is limiting, different to what happened at T320, which presented a greater content of $\mathrm{Ca}$ in the root system.

\section{Discussion}

Stalk diameter was greatly affected by a rise in the dose of $\mathrm{Ca}$. The greatest $\mathrm{t}$ value was achieved at T240. Studies indicate that, without nutritional restriction of substrate, plants prioritize shoot development at the initial stage. Nevertheless, T320 caused a decrease in this variable, probably because of competitive inhibition between $\mathrm{Ca}$ and $\mathrm{K}$ and between $\mathrm{Ca}$ and $\mathrm{Mg}$, resulting in a diminution in growth due to the reduction in absorption of these nutrients (Tucci et al., 2008). Other variables such as stalk diameter, root length, SHDM and RDM also decreased at T320 when compared to $\mathrm{T} 240$.

Studies have shown the beneficial effect on mahogany development of an increase in $\mathrm{Ca}$ concentration both in nutrient solution and in soil, and in the latter by the action of liming (Souza et al., 2010; Pedroso et al., 2012). Silva Júnior et al. (2014) performed a study with Brazilian mahogany submitted to increasing doses of $\mathrm{Ca}$ and $\mathrm{B}$, and also found a decline in mahogany growth with the largest concentrations of such nutrients, probably due to a rise in toxicity.

The responses of mahogany growth in soil with added $\mathrm{Ca}$ can be explained by the basic effects of the nutrient: increasing soil $\mathrm{pH}$ with a consequent reduction in the concentration of aluminium and manganese, elevating the availability of phosphorus and other nutrients, and incrementing microbial activity. These effects, when combined, result in suitable development of the plant (Camargo et al., 2010; Arantes et al., 2011), where the great requirement of this nutrient by mahogany plants due to the various functions performed in vegetal metabolism, such as median lamella composition, enzyme activation and the formation of pectate, phytate and oxalate (Malavolta, 2006), is evident. On the other hand, the lack of response of the height of mahogany grown in soil to liming action was also observed by Silva et al. (2007) and Souza et al. (2010).

In a study carried out by Pedroso et al. (2012), an increase in SHDM/RDM was found with increasing doses of lime as a Ca source in Yellow Oxisol. This means that in treatments with a smaller quantity of lime and a smaller increase in $\mathrm{pH}$, 
Table 1. Plant height, stalk diameter and root length in $\mathrm{cm}$. Shoot dry matter (SHDM), root dry matter (RDM) in $\mathrm{g}_{\text {plant }}{ }^{-1}$. Shoot dry matter/root dry matter ratio (SHDM/RDM) of young mahogany plants as a function of Ca dose.

\begin{tabular}{|c|c|c|c|c|c|c|}
\hline $\begin{array}{l}\text { Treatments } \\
\text { (doses of } \mathrm{Ca} \text { ) }\end{array}$ & Plant height & Stalk diameter & Root length & SHDM & RDM & SHDM/RDM \\
\hline TO & $31.6 \pm 1.60^{\mathrm{a}}$ & $0.78 \pm 0.02^{\mathrm{c \#}}$ & $10.9 \pm 0.71^{c}$ & $15.94 \pm 1.66^{b}$ & $1.82 \pm 0.18^{b}$ & 8.75 \\
\hline T80 & $40.4 \pm 2.99^{\mathrm{a}}$ & $0.83 \pm 0.04^{b c}$ & $9.94 \pm 0.75^{b c}$ & $20.62 \pm 2.21^{b}$ & $1.94 \pm 0.34^{\mathrm{b}}$ & 11.40 \\
\hline T160 & $40.0 \pm 2.25^{a}$ & $0.95 \pm 0.07^{\mathrm{ab}}$ & $10.6 \pm 0.86^{\mathrm{ab}}$ & $24.02 \pm 3.31^{\mathrm{ab}}$ & $2.88 \pm 0.45^{\mathrm{ab}}$ & 8.44 \\
\hline T240 & $39.4 \pm 5.52^{a}$ & $1.02 \pm 0.03^{\mathrm{a}}$ & $12.3 \pm 0.62^{\mathrm{a}}$ & $31.66 \pm 1.33^{\mathrm{a}}$ & $3.31 \pm 0.26^{\mathrm{a}}$ & 9.88 \\
\hline T320 & $39.1 \pm 1.30^{\mathrm{a}}$ & $0.89 \pm 0.02^{\mathrm{abc}}$ & $9.0 \pm 0.32^{b c}$ & $21.33 \pm 1.53^{b}$ & $2.24 \pm 0.23^{b}$ & 9.91 \\
\hline Linear regression & ns & ns & ns & ns & ns & ns \\
\hline$R^{2}$ & 0.37 & 0.46 & 0.03 & 0.35 & 0.30 & 0.01 \\
\hline Quadratic regression & ns & * & $*$ & $* *$ & * & ns \\
\hline$R^{2}$ & 0.67 & 0.59 & 0.19 & 0.71 & 0.67 & 0.02 \\
\hline
\end{tabular}

Linear regression: $y=a+b x$; quadratic regression: $y=a+b x+c x^{2} ; n s=$ non-significant; ${ }^{* *}=$ significant at $1 \%{ }^{*}=$ significant at $5 \%{ }^{\#}$ Means followed by the same letter in the same column did not differ significantly at $5 \%$ probability by Tukey's test.

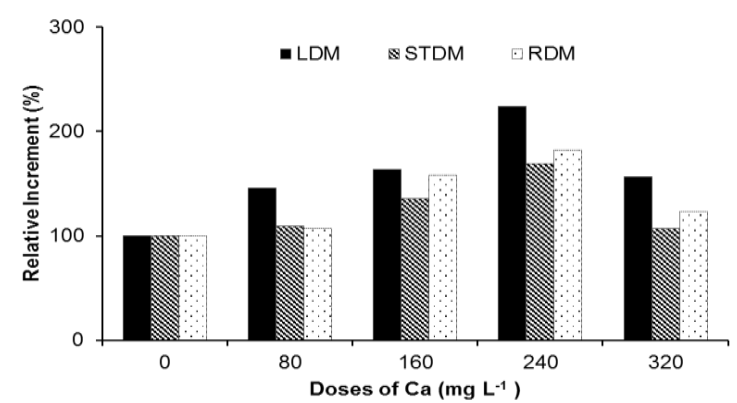

Fig 1. Relative increment of LDM, STDM and RDM of young mahogany (Swietenia macrophylla King) plants as a function of Ca dose.

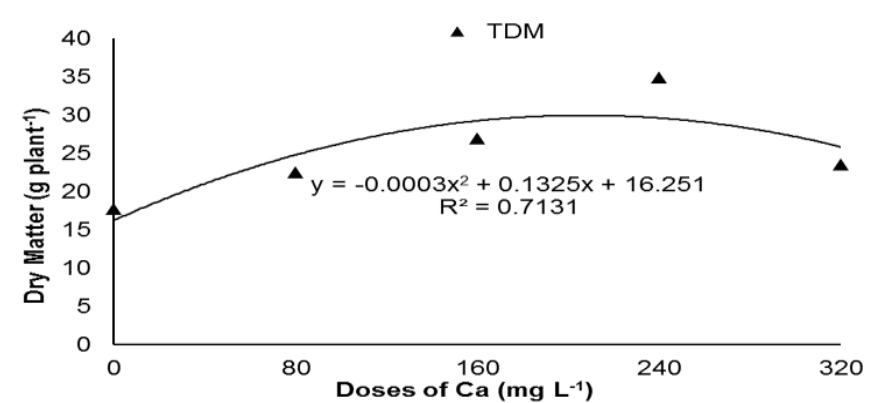

Fig 2. TDM of young mahogany (Swietenia macrophylla King) plants as a function of Ca dose.

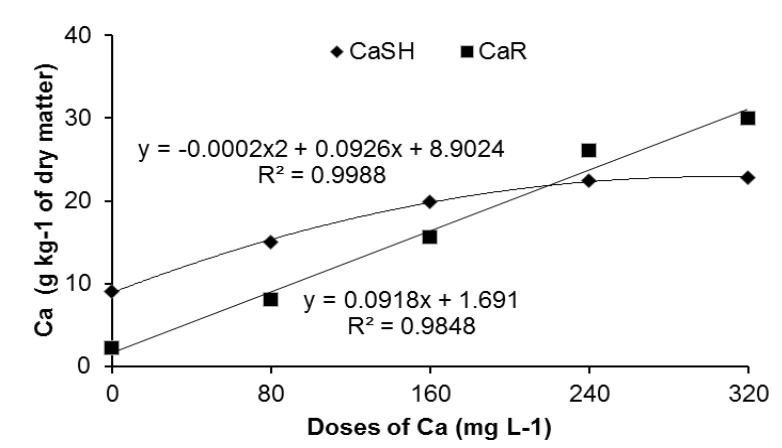

Fig 3. CaSH and CaR of young mahogany (Swietenia macrophylla King) plants as a function of Ca dose. 
a larger amount of RDM was found. This difference in culture medium could explain the results achieved in the present study since the $\mathrm{pH}$ of the nutrient solution was fixed daily, and the availability of other nutrients was maintained at levels adequate for plant nutrition.

The results for stalk diameter showed optimum production between 160 and $240 \mathrm{mg} \mathrm{L}^{-1}$ of $\mathrm{Ca}$ and agreed with those of Silva et al. (2007) who observed an increase in the diameter of mahogany seedlings in response to liming $\left(2.5 \mathrm{t} \mathrm{ha}^{-1}\right)$. Such a result was related to nutrient absorption which was greater on application of lime, whereas in treatments with greater values for stalk diameter, the greatest values for nutrient absorption were also verified.

According to the order of nutrient requirement obtained by Viégas et al. (2012), Ca is the third most demanded element for mahogany development; treatment of mahogany plants without calcium reduced the production of TDM by $71 \%$. In another study, a $25 \%$ reduction in dry matter production was found for mahogany plants with no application of Ca (Wallau et al., 2008). In a study with African mahogany (Khaya ivorensis A. Chev.) seedlings in nutrient solution, Corciolli et al. (2016) found that Ca was the second most required element by plants, of the 12 macro and micro nutrients evaluated.

The more elevated RPI in leaves, stalk and roots between treatments with 160 and $240 \mathrm{mg} \mathrm{L}^{-1}$ of Ca evidences the importance of $\mathrm{Ca}$ in plant vegetative growth, especially in the root system, by taking part in cell elongation and structuration and influencing ionic absorption. Barroso et al. (2005) also observed decreased accumulation of SHDM in teak (Tectona grandis L.f.) seedlings cultivated with a lack of $\mathrm{Ca}$ in the nutrient solution. However, a decrease in RPI was observed for treatment with $320 \mathrm{mg} \mathrm{L}^{-1}$ of $\mathrm{Ca}$.

The $\mathrm{CL}$ of an element for a specific crop suggests a concentration of the nutrient adequate for its full development. Below this level, production becomes limited, and above this level, production becomes non-economic and probably toxic to the plant (Malavolta, 2006). This knowledge of the effect of the $\mathrm{CL}$ of a nutrient is important for understanding the behaviour of $\mathrm{Ca}$ concentration in mahogany seedlings. With these results, it is possible to perceive that Ca shows little redistribution in plants, which is explained by its structural function in the composition of pectate for cell wall formation.

\section{Materials and Methods}

Plant materials must be explained here such as species variety, age, how they were grown from seedling, etc. Characterization of the experiment location

The experiment was performed in a greenhouse owned by the Instituto de Ciências Agrárias, Universidade Federal Rural da Amazônia, Belém, PA ( $\left.1^{\circ} 28^{\prime} 0^{\prime \prime} \mathrm{S} ; 48^{\circ} 27^{\prime} 0^{\prime \prime} \mathrm{W}\right)$ from September 2004 to February 2005. The air temperature ranged from 24 to $30^{\circ} \mathrm{C}$. The climate is tropical rainy, classified as Afi according to Köppen's classification (Watrin and Homma, 2011).

\section{Seedling selection and experiment implementation}

The seeds were derived from matrices of 15-year-old mahogany trees from Tramontina Farm in Aurora do Pará, State of Pará. After 52 days of germination, selection of mahogany seedlings was performed by homogenization according to size. These seedlings were transplanted into plastic pots with a volumetric capacity of $4 \mathrm{~L}$ containing milled silica-type coarse sand, number zero (silicon oxide), manufactured by Ventruz Minérios Ltda. Each pot contained one plant. A 2-mm diameter flexible hose was inserted at the base of each pot to allow the drainage of solution by gravity.

The seedlings were 45 days old and had four well-defined leaves when they were transplanted and grown in Hoagland and Arnon complete nutrient solution (1950), modified according to Epstein (1975) for suitable osmotic pressure (between 0.5 and $1.5 \mathrm{~atm}$ ), for a period of 75 days, in order to provide proper conditions for seedling development until application of treatments. During the experiment, the nutrient solution was applied in the morning between 7 and $8 \mathrm{~h}$, and drained daily in the afternoon, with the roots flooded for $10 \mathrm{~h} \mathrm{day}^{-1}$. The volume of solution that was lost by evapotranspiration was replaced with distilled water every morning. Nutrient solution was changed weekly by adjusting the solution $\mathrm{pH}$ to 6.0 with a diluted solution of $\mathrm{HCl}$ $1 \mathrm{~mol} \mathrm{~L}^{-1}$ or $\mathrm{NaOH} 1 \mathrm{~mol} \mathrm{~L}^{-1}$.

\section{Preparing and applying Ca doses}

The concentrations of $\mathrm{Ca}\left(\mathrm{mL} \mathrm{L}^{-1}\right)$ added into doses of 80 and $169 \mathrm{mg} \mathrm{L}^{-1}$ corresponded to 2 and $4 \mathrm{~mL} \mathrm{~L}^{-1}$ of $\mathrm{Ca}\left(\mathrm{NO}_{3}\right)_{2} \cdot 4 \mathrm{H}_{2} \mathrm{O}$ $1 \mathrm{M}$, respectively. The dose of $240 \mathrm{mg} \mathrm{L}^{-1}$ corresponded to 4 and $2 \mathrm{ml} \mathrm{L}^{-1}$ of $\mathrm{Ca}\left(\mathrm{NO}_{3}\right)_{2} \cdot 4 \mathrm{H}_{2} \mathrm{O} 1 \mathrm{M}$ and $\mathrm{CaCl}_{2} 1 \mathrm{M}$, respectively; the dose of $320 \mathrm{mg} \mathrm{L}^{-1}$ corresponded to 4 and 4 $\mathrm{ml} \mathrm{L}^{-1}$ of $\mathrm{Ca}\left(\mathrm{NO}_{3}\right)_{2} \cdot 4 \mathrm{H}_{2} \mathrm{O} 1 \mathrm{M}$ and $\mathrm{CaCl}_{2} 1 \mathrm{M}$, respectively.

\section{Experimental design and treatments}

The experimental design was completely randomized, with five treatments corresponding to the following $\mathrm{Ca}$ concentrations: 0 (T0), 80 (T80), 160 (T160), 240 (T240) and 320 (T320) $\mathrm{mg} \mathrm{L}^{-1}$. Each treatment had five replications, which were composed of one plant each; 127 days after emergence, treatments were applied during a 71-day period.

\section{Variables analysed}

At the end of the experiment, some variables such as plant height, stalk diameter and root length were evaluated. All measurements were made with a digital caliper rule. Additionally, the seedlings were collected and partitioned into leaves, stalks and roots. These vegetative parts were submitted to drying in a forced-air ventilation oven at $70{ }^{\circ} \mathrm{C}$ until constant weight was obtained. For dry matter, the following variables were determined: SHDM, RDM, STDM, LDM, TDM and SHDM/RDM ratio. Thereafter, the dried samples were milled in a Willey-type mill. From these measurements, the RPI of stalks, leaves and roots was determined. 
The milled samples were submitted to nitric per chloric digestion for determination of $\mathrm{CaSH}$ and $\mathrm{CaR}$ according to the methodology of Malavolta et al. (1997).

DMPE was determined from the first derivate of the equation fitted to TDM as a dependent variable of the applied doses of $\mathrm{Ca}$. To ascertain DMEE, doses of $\mathrm{Ca}$ accounted for $90 \%$ of the production. The $\mathrm{CL}$ of $\mathrm{Ca}$ for SHDM production was estimated by replacing DMEE in the equation for $\mathrm{CaSH}$. A relative increase was found for leaves, stalks and roots, considering the dry matter of the control treatment (absence of $\mathrm{Ca}$ ) as a reference.

\section{Statistical analysis}

Data were analysed using SPSS 17.0 software by the F-test for analysis of variance (ANOVA) and Dunnett's test for comparison of means at $5 \%$ significance $(p<0.05)$. Furthermore, linear and quadratic regression equations were adjusted for the variables analysed.

\section{Conclusion}

Calcium provides an increase in stalk diameter, root length, SHDM and RDM up to a dose of $240 \mathrm{mg} \mathrm{L}^{-1}$ in mahogany seedlings cultivated in nutrient solution. DMEE for TDM production in young mahogany plants is $119 \mathrm{mg} \mathrm{L}^{-1}$. The $\mathrm{CL}$ for $\mathrm{Ca}$ in the shoots is $17.10 \mathrm{~g} \mathrm{~kg}^{-1}$ of dry matter.

\section{References}

Arantes SACM, Lavorenti A, Torniselo VL (2011) Efeito da calagem na mineralização do ${ }^{14}$ glifosato em solos. Cienc Agrotec. 35(2): 234-241.

Barroso DG, Figueiredo FAMMA, Pereira RC, Mendonça AVR, Silva LC (2005) Diagnóstico de deficiências de macronutrientes em mudas de teca. Rev Árvore. 29(5): 671-679.

Camargo MS (2010) Fósforo em solos de cerrado submetidos à calagem. Biosci J. 26(2): 187-194.

Corciolli G, Borges JD, Jesus RP (2014) Sintomas de deficiência nutricional de macronutrientes em mudas de Khaya ivorensis cultivadas em solução nutritiva. Pesquisa Flor Brasil. 34(78): 159-164.

Epstein E (1975) Nutrição Mineral de Plantas: Princípios e Perspectivas, 1st edn. Editora USP, São Paulo.

Fernandes AR, Braz AMS, Maia PR, Viégas IJM (2013) Phosphorus fertilization and base saturation in the formation of Swietenia macrophyla seedlings. Rev Ciênc Agrar. 56(3): 261-267.

Free C, Landis RM, Grogan J, Schulze MD, Lentini M, Dünisch O (2014) Management implications of long-term tree growth and mortality trees: a modeling study of big-leaf mahogany (Swietenia macrophylla) in the Brazilian Amazon. Forest Ecol Manag. 320: 46-54.

Hoagland DR, Arnon DI (1950) The water culture method for growing plants without soil (Circular 347). University of California of Agriculture Experimental Station, California.

Malavolta E (2006) Manual de Nutrição Mineral de Plantas, 1st edn. Ceres, Piracicaba.
Malavolta E, Vitti GC, Oliveira AS (1997) Avaliação do Estado Nutricional das Plantas: Princípios e Aplicações, 2nd edn. Potafos, São Paulo.

Pedroso AJS, Silva Júnior ML, Silva GR, Ohashi OS, Birani SM, Leal NC, Melo VS, Teixeira OMM, Lobato AKS, Oliveira Neto CF, Silva RTL, Ruivo MLP (2012) Influence of liming and boron on development of young Swietenia macrophylla plants grown in Yellow Oxisol. J Food Agric Environ. 10(2): 1257-1261.

Rocha JBO, Pozza AAA, Carvalho JG, Silva CA, Curi N (2008). Efeito da calagem na nutrição mineral e no crescimento inicial do eucalipto a campo em Latossolo húmico da Zona da Mata (MG). Sci For. 36(80): 255-263.

Rocha JEC, Brasil Neto AB, Noronha NC, Gama MAP, Carvalho EJM, Silva AR, Santos CRC (2016) Organic matter and physical-hydric quality of an Oxisol under eucalypt planting and abandoned pasture. Cerne. 22(4): 381-388.

Silva ARM, Tucci CAF, Lima HN, Figueiredo AF (2007) Doses crescentes de corretivo na formação de mudas de mogno (Swietenia macrophylla King). Acta Amazon. 37(2): 195200.

Silva Júnior ML, Souza Júnior JC, Braga ACM, Ohashi OS, Melo VS, Silva GR, Pedroso AJ, Viégas JM, Saldanha ECM (2014) Crescimento de mogno-brasileiro e resistência a Hypsipyla grandella em função do cálcio e do boro. Rev Árvore. 38(6): 1085-1094.

Souza CAS, Tucci CAF, Silva JF, Ribeiro WO (2010) Exigências nutricionais e crescimento de plantas de mogno (Swietenia macrophylla King.). Acta Amazon. 40(3): 515-522.

Souza CR, Lima RMB, Azevedo CP, Rossi LMB (2008) Desempenho de espécies florestais para uso múltiplo na Amazônia. Sci For. 36(77): 7-14.

Tucci CAF, Lima HN, Lessa JF (2009) Adubação nitrogenada na produção de mudas de mogno (Swietenia macrophylla King). Acta Amazon. 39: 289-294.

Tucci CAF, Lima HN, Souza PA, Venturin N (2008) Efeitos de doses crescentes de calcário na produção de mudas de sumaúma (Ceiba pentandra L. Gaertn). Floresta. 38(2): 295-302.

Tucci CAF, Santos JZL, Silva Júnior CH, Souza PA, Batista IMP, Venturin N (2011) Desenvolvimento de mudas de Swietenia macrophylla em resposta a nitrogênio, fósforo e potássio. Floresta. 41(3): 481-490.

Tucci CAF, Souza PA, Venturin N, Barros JG (2007) Calagem e adubação para a produção de mudas de mogno (Swietenia macrophylla King). Cerne. 13(3): 299-397.

Viégas IJM, Lobato AKS, Rodrigues MFS, Cunha RLM, Frazão DAC, Oliveira Neto CF, Conceição HEO, Guedes SEM, Alves GAR, Silva SP (2012) Visual symptoms and growth parameters linked to deficiency of macronutrients in young Swietenia macrophylla plants. J Food Agric Environ. 10(1): 937-940.

Wallau RLR, Borges AR, Almeida DR, Camargos SL (2008) Sintomas de deficiências nutricionais em mudas de mogno cultivadas em solução nutritiva. Cerne. 14(4): 304-313.

Watrin OS, Homma AKO (2011) Evolução do Uso da Terra do Engenho Murutucu: História, Geografia e Ecologia, 1st edn. Belém, Embrapa Amazônia Oriental. 